\title{
PAVING THE WAY FOR INTERRELIGIOUS DIALOGUE, TOLERANCE, AND HARMONY: Following Mukti Ali's Path
}

\author{
Faisal Ismail \\ Sunan Kalijaga State Islamic University, Yogyakarta, Indonesia
}

\begin{abstract}
A known Indonesian Muslim scholar Mukti Ali (1923-2004) was very much concerned with dialogue, tolerance, and harmony among the people of different traditions, cultures, and religions. In his many academic works, be stressesed the importance of promoting, strengthening, and maintaining intercultural and interreligious dialogue, tolerance, and harmony. Not only did he produce various academic works, but also made efforts in putting his intercultural and interreligious ideas into practice. Both as a scholar and expert in the comparative study of religions and as Minister of Religious Affairs of the Republic of Indonesia (1971-1978), Mukti Ali endlessly promoted intercultural and interreliginos diologue, tolerance, and harmony. Realizing that Indonesia is a pluralistic society, Mukti Ali adopted an approach called 'agree in disagreement' in the effort of creating and supporting tolerance, harmony, and security among people of different religious traditions. This paper will highlight the principles and values which Mukti Ali struggled for during his long administrative and academic careers.
\end{abstract}

Mukti Ali (1923-2004) adalah salah seorang intelektual Muslim ternama di Indonesia. Dia dedikasikan hidupnya untuk menyemai dialog, toleransi dan kehidupan harmonis antar tradisi, budaya dan agama yang beragam. Dalam berbagai karya akademiknya, Mukti Ali selalu menekankan pentingnya kehidupan harmonis dan toleransi antar pemeluk agama dan budaya. Lebih dari itu, dia melampani hanya sekedar batas pemikiran dengan 
mengimplementasikan gagasan-gagasannya tersebut. Sebagai seorang ilmuwan dengan keablian perbandingan agama dan sebagai Menteri Agama RI (19711978), Mukti Ali dengan kukuh memperjuangkan dialog, toleransi dan kehidupan harmonis antar agama dan budaya. Mukti Ali sadar, Indonesia adalah negara yang plural, karena itu dia menawarkan pendekatan "agree in disagreement" untuk menciptakan harmoni dan toleransi tersebut. Tulisan ini mengulas prinsip dan nilai yang diperjuangkan Mukti Ali selama karir akademiknya dan sebagai Menteri Agama.]

\section{A. Introduction}

Indonesia is a country that consists of more than 17,000 islands which are spread out from Sabang (Aceh) in the West to Merauke (Papua) in the East with different ethnic groups, local languages, religions, traditions, arts, and cultures. Indonesia is a multi-ethnic, multicultural, and multi-religious society. The world religions -namely Islam, Christianity, Hinduism, and Buddhism- are represented in the country, in addition to a variety of indigenous beliefs. Hildred Geertz accurately depicts the plurality and diversity of Indonesian society when she wrote:

There are over three hundred different ethnic groups in Indonesia, each with its own cultural identity, and more than two hundred and fifty distinct languages are spoken. ... nearly all the important world religions are represented, in addition to a wide range of indigenous ones. ${ }^{1}$

Being a diverse and pluralistic society, Indonesia has strengths and yet weakness. Its main strength lies in the fact that Indonesian society is very rich in terms of traditions, arts, cultures, and spiritual matters. Its main weakness will reveal itself if Indonesia fails to maintain the diversity and plurality of its society. Tensions and conflicts between ethnic groups, social groups, and religious communities can occur any time. This is one of the main problems of Indonesian society faces today. In the face of this fragile condition, it is very important for all religious groups to maintain and strengthen dialogue and tolerance among communities of different religions, traditions, and cultures so that intercultural and interreligious harmony, security, and peace will be preserved in the country.

Indonesians have to recall Mukti Ali when talking about modern

${ }^{1}$ Hildred Geertz, "Indonesian Cultures and Communities," in Ruth T. McVey (ed.), Indonesia (New Haven: Yale University Press, 1963), p. 24. 
concepts, such as interreligious dialogue, tolerance, and harmony which the modern state of Indonesia should uphold for the sake of its own survival. Ali was a Muslim scholar who dedicated himself to promoting and strengthening dialogue and tolerance among communities of different religions, faiths, and cultures during most of his lifetime. His ideas remain important and relevant today so much so that scholars and researchers still need to his ideas and put in the context of Indonesian pluralistic society. It is no exaggeration that many have regarded Mukti Ali as the initiator of interreligious dialogue, tolerance, and harmony in the country. Serving as a professor at the Faculty of Ushuluddin (Islamic Theology), Sunan Kalijaga State Institute of Islamic Studies (IAIN, Institut Agama Islam Sunan Kalijaga), Yogyakarta, Mukti Ali produced a large number of important academic works on the comparative study of religions, a subject that he was deeply interested in since his student years at McGill University, Montreal, Canada. During his long academic career at the IAIN, he became increasingly interested in the subject and he made it his specialisation. Over time he became a renowned expert and a respected scholar of the comparative study of religions both in Indonesia and outside the country.

In fact, various leaders of religious groups with different faiths in Indonesia welcomed Mukti Ali's ideas on these subjects. As stated above, Indonesia is a pluralistic society with a plethora of ethnic variation, religions, traditions, arts, cultures, and local languages. These conditions need to be understood as important constituents of natural growth and social development that is also witnessed in many other communities in the world. No political leader or leader of religious groups in Indonesia can ignore this socio-religious and socio-cultural reality-well preserved in the national Indonesian motto "Bhinneka Tunggal Ika"2 (Unity in Diversity) written on a ribbon hanged on the claws of national symbol of eagle (garuda). However, how the Indonesian government, including all religious communities, and ethnic groups, guard this pluralist and

${ }^{2}$ Bhinneka Tunggal Ika is an expression derived from the Old Javanese poem Kakawin Sutasoma which in Indonesian means "berbeda-beda tetapi tetap satu" (Unity in Diversity). In 1945, the founding fathers of the Republic of Indonesia adopted this expression as its national motto for the Free State of Indonesia. It reflects Indonesian society's plurality and diversity, which should be maintained and preserved in and as one nation. 
multicultural characters with proper policies is a subject of everlasting discussion.

All in all, there is no doubt that Mukti Ali played a pivotal role in the process of creating promoting harmony among religious groups in Indonesia during his administrative career. Additionally, his ideas on interreligious dialogue and tolerance have had far-reaching implications for religious communities in Indonesia. This paper will endeavour to examine Mukti Ali's role and his contribution as a scholar who dedicated himself fully to this cause. Before discussing this subject further, it is necessary to introduce Mukti Ali's background, his life, education, and career.

\section{B. Life, Education, Position, and Role}

Mukti Ali was born in Cepu, Blora, Central Java, on 23 August 1923. He married Siti Asmadah in 1959 and they had a daughter and two sons. Mukti Ali passed away on 5 May 2004 in Yogyakarta at the age of eighty-one after having received medical treatment for some months at the Dr. Sardjito Hospital in Yogyakarta. Friends, colleagues, students, sympathisers, and other Muslims came to Mukti Ali's house in the Sagan District of Yogyakarta, to perform ta'ziyah ${ }^{3}$ and to pay him their last and sincere tribute. His death was felt as a big loss to his academic circle, the IAIN Sunan Kalijaga. Family members, friends, colleagues, IAIN lectures, students, and other Muslims performed salat jenaza $b^{4}$ before Mukti Ali's body was interred at the IAIN Sunan Kalijaga's cemetery complex. ${ }^{5}$

Mukti Ali's father was Haji Abu Ali and his mother Hajjah Khadijah. Mukti Ali was one of Abu Ali's six children. When he was young, he was

${ }^{3}$ Ta'ziyah is a visit by Muslims to the family members of a dead person to convey sadness and sympathy. During this visit, Muslims engage in do'a (prayer), asking God to forgive the deceased and asking His blessing for the members of his or her family.

${ }^{4}$ Salat jenazah is a salat performed by Muslims for a dead person. In this salat, Muslims say do'a (prayer) to Allah asking His forgiveness for the dead person.

${ }^{5}$ In my capacity as Secretary General of the Department of Religious Affairs, I attended Mukti Ali's funeral service. When I was a student at the Faculty of Tarbiyah, IAIN Sunan Kalijaga, I attended Mukti Ali's course on the comparative study of religions. When I sat his exam, I passed with a very good grade. Mukti Ali's course was taken not only by students of the Faculty of Ushuluddin, but also by students of the Faculty of Tarbiyah. 
called Boedjono. It was Kyai ${ }^{6}$ Hamid Dimyati (the leader of Pesantren Termas, Pacitan ${ }^{7}$ ) who, in 1943, gave him the name "Abdul Mukti." His father subsequently added "Ali" so that his name became Abdul Mukti. His father, who was a religious and generous man, was very concerned with his son's future education. In the morning, Mukti Ali was sent to a public elementary school in his village to study secular sciences, while in the afternoon he learned to read the Qur'an and studied religious sciences in an Islamic school. His father invited various kyais, including Kyai Usman, to teach Mukti Ali to read the Qur'an correctly and to teach him how to perform religious practices such as taking the ablution (wudhu) and how to execute prayers.

After passing his Klein Ambtenaar Examen (examination for low ranking civil servants) in Cepu, his father sent him to continue his studies at Pesantren Termas, Pacitan, Central Java. The main reason his father sent him to study at the pesantren rather than to a Dutch school was to educate him thoroughly in religious sciences so that he would grow up to become a devoted Muslim. In 1923, Pesantren Termas was one of the pesantrens in Java that already applied the madrasah school system by using a classical school system like that of the Dutch. Although these pesantrens already employed the madrasi system, in the learning and teaching process they continued to use their own traditional system, i.e. bandhongan (discussion) and sorogan (reading comprehension) by using classical Arabic books. ${ }^{8}$ His study at the pesantren enhanced and enriched Mukti Ali's understanding of the Qur'an and religious sciences. In addition to studying at Pesantren Termas, during the month of Ramadan, he took religious courses at Pesantren Tebuireng, and other pesantrens in Rembang, Lasem, and Padangan (East Java) broaden his knowledge in

${ }^{6}$ Kiai is a socio-religious title given to respected male persons who understand Islam very well. Usually, the title is used among members of the Nahdlatul Ulama.

${ }^{7}$ Pesantren is an Islamic boarding school. The leader of pesantren is called kiai, while students studying at pesantren are called santri. In Indonesia, especially in Java and Madura, there are thousands of pesantren and they are scattered over many parts of rural areas in the country.

${ }^{8}$ The classical Arabic books used in traditional pesantren are called 'kitab kuning' which literally means 'yellow books.' These books, written by ulama of the classical period of Islam (7-13 centuries AD), contain treatises on tafsir (Qur'anic interpretation), tawhid (Islamic theology), fiqh (Islamic jurisprudence), tasammuf (Islamic mysticism), and nahw-sharaf (Arabic linguistics and grammar). 
badith (prophetic tradition), fiqh (Islamic juriprudence), and nahw (Arabic grammar).

In 1945, Mukti Ali completed his studies at Pesantren Termas which had endowed him with a deep understanding of Islam and had turned him into an open-minded santri (Islamic student). In the following year, he was elected as a member of the People's Representative Council of the Blora Region representing the Masyumi Party. However, his involvement in politics was not to last long (only two years). In 1947, he decided to continue his studies and he enrolled as a student at the Islamic High School in Yogyakarta which was later transformed into the Islamic University of Indonesia (UII, Universitas Islam Indonesia). At the UII, Mukti Ali became acquainted with K.H. Mas Mansur, a wellknown lecturer and a leading figure of the Muhammadiyah. ${ }^{9}$ Besides taking courses on Islam with K.H. Mas Mansur at the UII, Mukti Ali also studied Islam privately with him at his house. This, of course, contributed to turning him into an open-minded student which was a very important factor in forging him into the pluralist he was later to become.

Not only did Mukti Ali become a very good student of K.H. Mas Mansur, he also joined his mentor's organisation, the Muhammadiyah. As a modernist movement, the Muhammadiyah calls for the use of $i j t i b \bar{d}$ in interpreting the Qur'an and sunna of the Prophet in formulating legal opinions (fatwa). Different from the Muhammadiyah, as a traditional organisation, the Nahdlatul Ulama ${ }^{10}$ prefers to apply taqlid and $i j m a^{-6}$ in formulating their fatwa $\bar{a}$. The close relation between Mukti Ali and K.H. Mas Mansur changed his religious views fundamentally and Mukti Ali abandoned his Nahdlatul Ulama traditional background and adopted the ideas of purification, reform, and modernisation the Muhammadiyah advocated. However, later he admitted that he was not officially registered

9 The Muhammadiyah is a Muslim modernist organisation, which was established by K.H. Ahmad Dahlan in 1912 in Yogyakarta. Usually, members of the Muhammadiyah originate from a background of teachers, intellectuals, traders, and the urban population. The Muhammadiyah is the largest organisation among Muslim modernist groups in Indonesia.

${ }^{10}$ The Nahdlatul Ulama is a Muslim traditionalist organisation set up by a group of ulama in 1926 in Surabaya, East Java. Its members usually come from a peasant background and from people living in rural areas. Traditionally, pesantrens join the Nahdlatul Ulama because of their shared religious culture and tradition. The Nahdlatul Ulama is the largest organisation among Muslim traditionalist groups in Indonesia. 
as a member of the Muhammadiyah but that he just had became one of the organisation's activists. ${ }^{11}$

In 1950, Mukti Ali went to Mecca to perform the hajj (the pilgrimage to the Holy Land, the fifth pillar of Islam) and used this opportunity to study Islam for some months in the Holy City. One year later, on the suggestion of $\mathrm{H}$. Imron Rosyadi, an officer of the Indonesian Haij Consulate, he went to Karachi (Pakistan) to pursue his studies at the Department of Islamic History, Faculty of Arabic Literature. Being a diligent and clever student, he worked very hard to finish his studies in time so that he could realise his study objectives according to plan. Mukti Ali's close friends who also studied at the same faculty include Khurshid Ahmad and Aziz Ahmad who later emerged as leading writers and creative intellectuals. Mukti Ali finally completed his Ph.D. program in five years. In 1955, after finishing his study in Pakistan, he did not return to Indonesia but went directly to Montreal, Canada, to take courses in the comparative study of religions in the M.A. program at the Institute of Islamic Studies, McGill University. ${ }^{12}$

During his study at the Institute of Islamic Studies, he became acquainted with Professor Wilfred Cantwell Smith with whom he took courses on the comparative study of religions. It is necessary to note that Professor Cantwell Smith was the founder of the Institute of Islamic Studies where Christian and Muslim students are able to study together. In Smith's view, the Institute was set up to build mutual understanding and respect between the West and Islam. Professor Smith's lectures enriched Mukti Ali's intellectual vision and broadened his horizon. At McGill, Mukti Ali was impressed by his professors' method of teaching through which they transferred as much of their knowledge as possible to their students. He also felt that class discussions and seminars were very good as they enhanced his understanding of a number of the subjects he took during his study at McGill. He illustrated his close relationship with Professor Smith by saying:

${ }^{11}$ Quoted in Ali Munhanif, "Prof. Dr. A. Mukti Ali: Modernisasi PolitikKeagamaan Orde Baru" in Azyumardi Azra and Saiful Umam, et al. (eds), Menteri-Menteri Agama Republik Indonesia: Biografi Sosial Politik (Jakarta: PPIM, 1989), pp. 278-279.

${ }^{12}$ Mukti Ali's M.A. thesis is entitled "The Muhammadiyah Movement: A Bibliographical Introduction." It is available at the Islamic Library of the Institute of Islamic Studies, McGill University. 
Before studying at McGill University in Canada, I had no idea about the comparative study of religions. My specialisation at the Faculty of Arabic Literature in Karachi was Islamic History. I was interested to take the courses offered by Prof. Niyazi Berkes from Turkey, Prof. William Bugli from the United Kingdom, and Prof. Bahy from Egypt, but I was more interested in Professor Smith's courses on the comparative study of religions for various reasons. Prof. Smith's method of teaching was excellent; he is a real expert in the comparative study of religions, and he introduced me to new ways of analysis and to new approaches to the study of Islam. He analysed the historical developments of religions by exploring their phenomena from various perspectives and in a comprehensive way. If I may, I would call it a "holistic approach" to the study of religions. This approach very much influenced my way of thinking and, in a broad sense, changes my attitude toward understanding life. ${ }^{13}$

Mukti Ali's background of studying at a public elementary school as well as at an Islamic school in his village, his studies at Pesantren Termas (Central Java), at the Faculty of Arabic Literature (Karachi), and at the Institute of Islamic Studies (Montreal) accumulated and they became important factors in making him an inclusive scholar. In other words, the combination of Mukti Ali's Islamic and Western educational backgrounds enabled him to emerge as an 'inclusive' scholar. It is believed that during his student years at McGill he began to build up a strong foundation for and firm commitment to the promotion and strengthening of interreligious dialogue and tolerance which subsequently became the main themes in Mukti Ali's ideas, thoughts, and views.

In 1957, Mukti Ali started his academic career as a teacher at the State Islamic High School (PTAIN, Perguruan Tinggi Agama Islam Negeri) in Yogyakarta, which was transformed into the State Institute of Islamic Studies (IAIN, Institut Agama Islam Negeri) in 1960 and was transformed yet again into the State Islamic University (UIN, Universitas Islam Negeri) Sunan Kalijaga ${ }^{14}$ in 2004. In addition to teaching at PTAIN, he also lectured at the State Academy of Islamic Studies (ADIA, Akademi

${ }^{13}$ Munhanif, "Prof. Dr. A. Mukti Ali: Modernisasi," p. 283.

${ }^{14}$ In addition to UIN Sunan Kalijaga Yogyakarta, there are five other UINs, namely UIN Syarif Hidayatullah (Jakarta), UIN Sunan Gunung Djati (Bandung), UIN Maulana Malik Ibrahim (Malang), UIN Alauddin (Makassar), and UIN Sultan Syarif Qasim (Pekanbaru). All these UINs were transformed from IAINs. 
Dinas Ilmu Agama) in Jakarta, which was later transformed into IAIN and later UIN Syarif Hidayatullah. ${ }^{15}$ When, in 1960, IAIN Sunan Kalijaga opened the new department of the Comparative Study of Religions, Mukti Ali was entrusted to serve as its head. This was absolutely the right choice since he was the right man in the right place. He also taught and delivered lectures on Islam at Christian and Catholic universities in Yogyakarta. For him, the course on the comparative study of religions was important, but more important still was its effect, namely heightened awareness of the importance to promote and strengthen dialogue and tolerance among communities of different religions, traditions, and cultures.

Mukti Ali obtained his professorship in 1971. Ali was also interested in joining discussions related to Islam and other current issues. Together with his young friends, Dawam Rahardjo, Kuntowijoyo, Syu'bah Asa, Djohan Efendi, Muin Umar, Simuh, Syamsuddin Abdullah, Wadjiz Anwar, and Ahmad Wahib, he established the Limited Group discussion which held a series of discussions in his house from 1967 until 1971. ${ }^{16}$ The discussions were held every Friday afternoon and raised various topics like Islam and Ideology, Islam and Politics, and Islam and Democracy and other themes that needed to be discussed at the time. The objective of the Limited Group discussions was to enrich and enlighten its participants' intellectual insights and to broaden their horizons so that they would become open-minded intellectuals. In line with this objective, non-Muslim scholars and intellectuals like B.J. Boland, Y.W.M. Bakker, Niels Mulder, and James Peacock were also invited to attend the Limited Group as speakers. This was very important for the participants at the discussions as they would become the future Muslim as well as Indonesian leaders who would be able to promote interfaith and intercultural dialogue and tolerance.

Subsequently, Mukti Ali was appointed Vice-rector I responsible for academic affairs at IAIN Sunan Kalijaga and again he was the right

${ }^{15}$ In 1960, PTAIN Yogyakarta and ADIA in Jakarta merged and restructured into two IAINs, namely IAIN Sunan Kalijaga in Yogyakarta and IAIN Syarif Hidayatullah in Jakarta respectively. Both became the origins of all other IAINs in almost all other Indonesian provinces today.

${ }^{16}$ Djohan Efendi and Ismet Natsir (eds), Pergolakan Pemikiran Islam: Catatan Harian Ahmad Wabib, Jakarta: LP3ES, 1981 
man in the right place. He immediately started to work hard and he made every effort to put his vision and mission into practice. In the 1970s, to improve the quality of the IAIN's teaching staff, Mukti Ali organised a Post Graduate Course (PGC) program which IAIN lectures were obliged to attend for three months. Lecturers who had completed this program were to continue by following another program called Post Graduate Studies (SPS, Studi Purna Sarjana). Both were non-degree programs. However, by attending the programs, the IAIN teaching staff members were enabled to develop and increase the quality of their knowledge, as well as their capability of teaching and conducting research, the method of their teaching, their ways of reasoning and argumentation, and their methodology in analysing cases and issues which had become the objects of their studies. Since the 1980s, a regular program called Program Pasca Sarjana (Program of Graduate Studies) was established and operated at IAIN Sunan Kalijaga. Officially, it offers M.A. and Ph.D. degree programs for those who completed their program. The Study Purna Sarjana, which Mukti Ali introduced was in fact the embryo of the Program Pasca Sarjana.

President Soeharto appointed Mukti Ali in 1971 as the Minister of Religious Affairs of the Republic of Indonesia. This appointment was made perhaps due to Ali's reputation in the comparative study of religions and his effort in promoting religious dialogue among communities of different religions, traditions, and cultures. He succeeded K.H. Mohammad Dahlan whose ministerial term had actually not finished yet. Mukti Ali served as Minister of Religious Affairs for two terms; the first lasted from 1971-1973 and the second from 1973-1978. When he had become Minister of Religious Affairs, Mukti Ali sent a large number of IAIN lectures to study at the Institute of Islamic Studies, McGill University, Montreal. Again, this move greatly contributed to the enhancement and development of the academic program at the IAIN as a whole. Many McGill alumni including Zaini Muchtarom and Murni Djamal occupied important positions at the Ministry of Religious Affairs. It was a real 'joke' at the time that strategic positions at IAINs and at the Ministry of Religious Affairs were dominated by the McGill 'Mafia.'

Mukti Ali made another breakthrough when he facilitated the creation of the Indonesian Council of Ulama (MUI, Majelis Ulama 
Indonesia) in 1975. In his view, the MUI was to be set up as a venue through which good communication and strong relations between the ulama in particular and Muslims in general and the government were to be maintained and there were to be no 'misunderstandings' between the two parties. Led by ulama who were experts in Islamic law, the MUI plays a pivotal role in formulating fatwa a for new religious issues arising among the Muslim community whose legal status are not specifically mentioned either in the Qur'an or in the sunna. Because the MUI issues fatwa , the Muslim community understands to which fatwa it should abide. Another function of the MUI is to communicate with the leaders of other religious councils such as the United Indonesian Churches (PGI, Persekutuan Gereja Indonesia) and to cooperate with them in social affairs. In other words, one of the functions of the MUI is to promote, preserve, and strengthen dialogue and tolerance among communities of different faiths, religions, and cultures. Mukti Ali's role, contribution, and legacy as Minister of Religious Affairs should be considered within this context.

While serving as the Minister of Religious Affairs, Mukti Ali criticised the weaknesses of the IAINs. He detected three weaknesses. First, they were weak in mastering foreign languages, particularly Arabic and English. Second, they were weak in scientific methodology. Third, they lacked the spirit for the pursuit of knowledge because of the moral weakness of its teaching staff. These weaknesses should be overcome so that the quality of the teaching staff, the academic programs, and the institution of the IAINs themselves would reach academic standards. For these reasons, Mukti Ali sent a large number of IAIN lectures to study at McGill and he set up two programs called Post Graduate Studies and Studi Purna Sarjana as already mentioned above. He also gave instructions to open foreign language programs, namely for Arabic and English, at every IAIN throughout the country so that students could master Arabic and English to enable them to explore knowledge and to conduct research at an academic level.

After serving as Minister of Religious Affairs, Mukti Ali returned to his old campus and resumed teaching as professor of Comparative Study of Religions at the Faculty of Ushuluddin and the Program Pasca Sarjana (Program of Graduate Studies) of IAIN Sunan Kalijaga, 
Yogyakarta. Like in the 1970s, he set up a discussion group at the IAIN encouraging lectures to actively write papers on interesting topics to be discussed. When not ill or having other activities, Mukti Ali himself actively presided over the discussions which were organised at Wisma Sejahtera every Friday evening from 1978-1993. ${ }^{17}$ In other words, he dedicated himself to these discussions uninterrupted for more than fifteen years. ${ }^{18}$ For each year, a schedule was made for these discussions for which each member of the IAIN's teaching staff was given the opportunity to write a paper or to participate in the discussions..$^{19}$ It is noteworthy that some IAIN lectures benefited from these discussions as well so that their intellectual capacities and research capabilities developed in line with academic standards.

However, President Soeharto once again appointed Mukti Ali as a member of the Supreme Advisory Council (DPA, Dewan Pertimbangan Agung). In addition, he was appointed a member of the People's Consultative Council for the period 1993 - 1998 representing functional and expert groups. He also held other important positions and he was a member of the Islamic Cultural Committee, UNISCO (based in Paris); member of the Advisory Council of Parliament of World Religions (New York); member of the Advisory Federation of World Peace; member of the Jakarta Academy of Culture; member of the National Council of Research; member of the Indonesian Academy of Science; and member of the Central Board of the Generation of $1945 .^{20}$

${ }^{17}$ The discussion program still continues at present and Professor Muhammad Abdul Karim of the Faculty of Adab acts as the moderator of the discussions.

${ }^{18}$ Djam'annuri (ed.), 70 Tabun H.A. Mukti Ali: Agama dan Masyarakat Yogyakarta: IAIN Sunan Kalijaga Press, 2001), p. 40. This book was dedicated to Professor Mukti Ali and published when he was seventy years old. Scholars, intellectuals, colleagues, and friends contributed articles to this book. Djam'annuri, one of Mukti Ali's students at the Faculty of Ushuluddin, IAIN (now UIN) Sunan Kalijaga, Yogyakarta, was the editor of the book and is a professor of the comparative study of religions at the Faculty of Ushuluddin.

${ }^{19}$ In the 1980s, as a lecturer at the Faculty of Dakwah, IAIN Sunan Kalijaga, I presented a paper entitled "The Dynamics of Islamic Culture and Civilisation" in the discussion. I remember that Professor Mukti Ali led the discussion. His comments on my paper and his suggestions, inputs, and opinions enriched and enlightened me.

${ }^{20}$ Munhanif, "Prof. Dr. A. Mukti Ali: Modernisasi," pp. 42-43. 


\section{Academic Works, Ideas, and Thoughts}

For me personally and perhaps for those who know him, Mukti Ali was a creative and prolific writer who produced more than thirty academic works. On one occasion in the 1980s, I met him at his house in the IAIN complex and I saw many books on the shelves in his guest room, some of which are old books he had studied at the Institute of Islamic Studies at McGill University, Montreal. In addition, Mukti Ali established a foundation called Jajasan Nida (Nida Foundation) ${ }^{21}$ which published many of his scientific writings.

In the following, I just want to present a little survey by illustrating, describing, and commenting on the contents of some of his works. When I was a student at the Faculty of Tarbiyah, IAIN Sunan Kalijaga (1967-1973), I was fortunate that I was able to buy and collect many of his books, especially those related to the courses he taught. Thus, my collection contains at least eighteen of Mukti Ali's academic works, consisting of between 45 to 50 pages, which I have kept them until today.

To present Mukti Ali's publications, they are as follows: Asal Usul Agama (The Origins of Religion), Ilmu Perbandingan Agama dan Metodosnya (Comparative Study of Religions and Its Methodology), Ke-Esaan Tuhan dalam Alqur'an (The Unity of God in the Qur'an), Etika Agama dalam Pembentukan Kepribadian Nasional (Religious Ethics in National Character Building), Pemberantasan Kemaksiatan dari Segi Agama Islam (Fighting Immorality from the Islamic Perspective), The Spread of Islam in Indonesia (in English), An Introduction to the Government of Acheh's Sultanate (in English), Pelbagai Persoalan Islam di Indonesia Dewasa Ini (Problems of Islam in Contemporary Indonesia), Agama dan Pembangunan di Indonesia (Religion and Development in Indonesia), Ibn Chaldun dan Asal Usul Sosiologi (Ibn Chaldun and the Origins of Sociology), Alam Pikiran Islam Modern di Indonesia (Modern Islamic Thought in Indonesia), Dialog Antaragama (Interreligious Dialogue), and Beberapa Pertimbangan tentang Peningkatan Mutu LAIN dan Kurikulum (Some Considerations to Improve the Quality of the IAIN and its Curriculum). ${ }^{22}$

${ }^{21}$ The name 'Nida' was taken from his beloved first daughter, Nidatul Hasanah. Nida is now a lecturer at the Faculty of Psychology, Gadjah Mada University, Yogyakarta.

${ }^{22}$ All these books were published by Jajasan Nida (Mukti Ali’s Foundation). For further information on other works written by Mukti Ali, see the list in the bibliography of this article. 
To illustrate the content of one of the books, in Modern Islamic Thought in Indonesia, Mukti Ali discusses the Muhammadiyah as a Muslim modernist movement but prior to discussing its role and contribution as a modernist movement, he outlines, among others, the role of Jamaluddin Al-Afghani, Muhammad Abduh, and Rashid Ridha who preached modernist ideas in the nineteen century. Their influence among Muslims in the Islamic World was far-reaching and widespread. It is believed that these reformers significantly influenced and inspired K.H. Ahmad Dahlan, the founder of the Muhammadiyah. Through the Muhammadiyah, established in Yogyakarta in 1912, Dahlan preached his ideas of reform that, according to Mukti Ali, may be summarised in four main objectives: 1) The purification of Indonesian Islam from the corrupting influences and practices; 2) The reformulation of Islamic doctrine in the light of modern thought; 3) The reformation of Muslim education; and 4) The defence of Islam against external influences and attacks. $^{23}$

Mukti Ali admits that he took over these objectives virtually unchanged from H.A.R. Gibb's words on page 33 in his book, Modern Trends in Islam, published by the University of Chicago in 1966 where Gibb analyses the basic principles of Muhammad Abduh's reform movement in Egypt. In Gibb's original words, the objective number 4 reads, "the defence of Islam against European influences and Christian attacks." ${ }^{24} \mathrm{I}$ agree with Mukti Ali's view that the goals of Abduh's reform program in Egypt are applicable to those of the Muhammadiyah reform movement in Indonesia. These can be seen from its efforts to establish modern schools, universities, clinics, hospitals, and orphanages in many parts of Indonesia. The Muhammadiyah has done very well in its efforts to purify Islamic doctrine from corrupting influences and practices. In terms of way of thinking, the Muhammadiyah -like Abduh- uses ijtihād (rational interpretation of the Qur'an and the sunna) rather than taqiid or ijmás which Muslim traditionalists utilise. Given these facts, Mukti Ali is correct when he said that the objectives of Abduh's reform movement in Egypt are generally applicable to those of the Muhammadiyah in Indonesia.

${ }^{23}$ Mukti Ali, Modern Islamic Thought in Indonesia (Jogjakarta: Jajasan Nida, 1969), p. 37.

${ }^{24}$ See H.A.R. Gibb, Modern Trends in Islam (Beirut: Librairie du Liban,1975), p.33. 
Mukti Ali also discusses the relationship between the state and religion in Indonesia that had become an actual issue in the 1970s. Scholars, intellectuals, and government dignitaries frequently discussed the issue. In response to this issue, he first stated that political leaders and thinkers always use a bipolar approach: a state is either secular or theocratic in nature. For Mukti, a secular state is a state where the life of the people is not related to religious values. In a secular state, religion is a private affair and has no place in the public space. Religion should not interfere in political affairs and state's policies. "God is dead in a secular state," said Mukti Ali. ${ }^{25}$ On the other hand, for him, a theocratic state is a state where the head of the state claims to be God's representative on earth whose words, decisions, deeds, and actions are final and absolute. ${ }^{26}$

After putting forward these main characteristics of the secular and the theocratic state, Mukti Ali emphasised that Indonesia has chosen its own path in determining the relation between state and religion. In his view, Indonesia is neither a theocratic nor a secular state; Indonesia is a Pancasila state in which all Indonesian people believe in the One and the Only God as expressed in the Pancasila's first principle. ${ }^{27}$ "In the Pancasila state God is alive, not dead," said Mukti Ali very confidently. The lives of the Indonesian people are grounded in religious moral values and spiritual principles that are important elements of 'the belief in the One and the Only God' as stated in the Pancasila. He stressed that these religious moral values and spiritual foundations are the core values for the Indonesian people in the implementation of development programs in its effort to achieve prosperity and happiness. ${ }^{28}$

In Indonesia in the 1970s, modernisation and development were heavily debated actual and widespread issues. Many scholars, intellectuals, government dignitaries, Islamists, humanists, and secularists responded to the issue from their own backgrounds, using their own arguments,

${ }^{25}$ Mukti Ali, "Indonesia Bukan Sekuler dan Tidak Theokratis" in his Agama dan Pembangunan di Indonessia (Jakarta: Departemen Agama RI, 1972), p. 64.

${ }^{26}$ Ibid.

${ }^{27}$ Pancasila is a Sanskrit compound; panca means five; sila means pillar. The five pillars of the Pancasila are: belief in the One and Only God; civilised humanity; unity of Indonesia; democracy; and social justice for all Indonesian people. The Pancasila is the philosophical basis of Indonesian State.

${ }^{28}$ Ali, "Indonesia Bukan Sekuler," p. 65. 
perspectives, and views. The debates concentrated on the issue whether Indonesia should follow and imitate a Western model of development and modernisation or another model that was more suitable for Indonesia as a developing and Muslim country. As a Muslim scholar and Minister of Religious Affairs, Mukti Ali proposed his idea that "integral human development" should be the basic principle of the implementation of the development program in Indonesia. He explained that,

Integral human development involves far more than economic growth. In the uncritical pursuit of the latter values important to the former may be sacrificed. Development includes not only measurable economic and social 'goods', but also a relational, social-psychological, and spiritual environment in which individuals and groups exist. Development is not synonymous with becoming richer, either materially (technical, Marxist) or socially (humanist). ${ }^{29}$

Thus, according to Mukti Ali, development is not a process of mere economic growth that makes people materially prosperous, but, in his words:

Development puts as much emphasis on human integration and deliberation as it does on economic and social output. Development is the process of the creation of a new man, a man liberated from the physical constrains of hunger, disease, superstition, utter dependence on ill-understood natural forces; but also a man liberated from the spiritual constrains of his own egoism. Development is thus social and individual, material and spiritual. ${ }^{30}$

It is obvious that Mukti Ali had a clear vision and a deep understanding of the condition of Indonesian society which is deeply rooted in religious moral values and the spiritual meanings of life. Development does not only deal with material things, but also with spiritual matters that cannot be ignored in the development process.

For Mukti Ali, there is no universal model of development. Each country is free to choose and establish its own model in accordance with its social, cultural, religious, and political conditions. It implies that Western models of development are suitable for Western countries, but

${ }^{29}$ Mukti Ali, "The Effect of Regional and International Cooperation for Economic Development (Non-Economic)," Agama dan Pembangunan, pp. 28-29.

${ }^{30}$ Ibid., p. 29. 
may not be suitable for other countries, particularly Indonesia. Moreover, he opined that development and modernisation are not identical to Westernisation. He emphasised the use of a pluralistic strategy of change and liberation in the process of development and modernisation in Indonesia. ${ }^{31}$ This was Mukti Ali's response to the issue of development and modernisation in the 1970s. The Indonesian government adopted Mukti Ali's strategic ideas on development and modernisation. Since the 1970s, Mukti Ali's adage "pembangunan manusia seutuhnya" (integral human development) has become a widespread and often used maxim, for instance, in the General Outlines of State Policies (GBHN, GarisGaris Besar Haluan Negara), in President Soeharto's speeches, and even in today's intellectual discourses. There is no doubt that it was Mukti Ali who coined this maxim.

As a scholar, Mukti Ali employed an approach he called "scientificcum-doctrinarian" ${ }^{32}$ which combines a normative and an empirical approach in the study of Islam. By using this approach, Islam can be analysed and interpreted doctrinally, historically, and empirically. He did not apply a normative approach in his study of Islam because this kind of approach is scriptural in nature and merely refers and subscribes to religious texts in understanding Islam. Therefore, a normative approach should be combined and integrated with an empirical approach by considering and understanding the historical, social, and cultural setting in studying and analysing Islam in the life of a society. When Islam arrived and started to interact with the life of a society, that society was not without traditions and cultures because they already existed there. Thus, Islam, local traditions and indigenous cultures intermingled in such a way that a process of acculturation took place. By using the "scientific-cum-doctrinarian" approach, Islam can be explored from various interdisciplinary approaches and from variable dimensions that cannot be separated or ignored. Mukti Ali called this a 'holistic' approach. ${ }^{33}$

\footnotetext{
${ }^{31}$ Ibid.

${ }^{32}$ Mukti Ali, Metode Memahami Agama Islam (Jakarta: Bulan Bintang, 1991), pp. $31-32$.

${ }^{33}$ Ibid., p. 32.
} 


\section{Interreligious Dialogue, Tolerance, and Harmony}

From 1955-1957, Mukti Ali attended his M.A. program at the Institute of Islamic Studies, McGill University, and he specialised in the comparative study of religions. He finished his studies in time and obtained his M.A. degree. When IAIN Sunan Kalijaga opened its new department of the comparative study of religions, Mukti Ali was appointed as its head, which was completely spot on because of his educational background and he served as its head for many years. In Indonesia in the 1960s, very few scholars specialised in the comparative study of religions, and those who had graduated from a Western university were but fewer. At that time, Mukti Ali was one of those few.

On 12 July 1964, IAIN Sunan Kalijaga commemorated its 4th anniversary and on that occasion, Mukti Ali delivered a speech entitled Ilmu Perbandingan Agama: Sebuah Pembahasan tentang Methodos dan Sistima (Comparison of Religions: A Study of Methodology and System). His speech was published in the form of a small booklet by Al-Falah Publisher under the same title. ${ }^{34}$ One of the important points he stressed in his speech was that the comparison of religions was not an apology and that it was not a tool to be used to defend one's faith or religion, but rather to understand the existence, growth, development, function, and natural characteristics of religion. ${ }^{35}$ Was it possible, he asked, for someone who already had his/her own religion to sympathise with people of other faiths or religions? Mukti Ali's answer to this question was: "yes." Although someone already adhered to a religion, he/she could still appreciate the religious experiences of people adhering to other faiths and religions. Each person has the fundamental moral obligation to respect other people, including their religions and faiths.

When studying other faiths and religions, scholars who specialised in the comparative study of religions do not need to put aside their own religion - even for a short while- in order to remain 'objective'. They should firmly believe in their own religion while differences and similarities between their religion and other religions should be unveiled, understood, and explained academically and scientifically. In this way,

${ }^{34}$ Mukti Ali, Ilmu Perbandingan Agama: Sebuah Pembahasan tentang Methodos dan Sistima (Jogjakarta: PT Al-Falah, 1964).

35 Ibid., p. 7. 
mutual sympathy and respect among people of different faiths and religions could be created and concretised. For a Muslim, the comparative study of religions is a tool to understand how God provided guidance to man and how man responded to His guidance. He concluded that scholars should use the science of religion as a highly useful and important scientific tool in order to understanding their own and other people's religions. ${ }^{36}$

Furthermore, Mukti Ali observed the relations between Hindus and Muslims in the country. Far before Islam came to Indonesia in the 7th century and the Islamisation process started in the 13th century, the people in the archipelago were Hindus, Buddhists, and animists. Like historians, Mukti Ali held the view that Islam came to Indonesia in a peaceful way. He outlined the process of the arrival of Islam in Indonesia in a paper entitled the Spread of Islam in Indonesia which he presented at the Congress on Cultural Freedom held in Karachi, Pakistan, in February 1959 and which was published in an official journal of IAIN Sunan Kalijaga, Al-Djami'ah, nos. 4 (April 1962) and 5 (May 1962). Later, in March 1970, Jajasan Nida published the paper in the hope that it would be widely read by students, scholars, and researchers.

In this paper, Mukti Ali described the spread of Islam in Indonesia by stating that, before Islam came to Indonesia, Indonesian people were animists, Hindus, and Buddhists. When Islam came to the archipelago, a very fast and extensive Islamisation took place. Animists, Hindus, and Buddhists converted to Islam in very large numbers. In spreading Islam, Muslims did not use violent means or armed struggle but indigenous cultural feats such as wayang (leather puppet) and gamelan (musical instruments) to attract people to embrace Islam. In Java, the Wali Sanga (the nine walis par excellence) ${ }^{37}$ were famous and staunch Muslim preachers who greatly contributed to the spread of Islam. Consequently, Islam became the dominant religion throughout the country. Mukti Ali stressed that when Islam came to Indonesia, there were no conflicts between Islam as the new religion and the old indigenous beliefs and that the Muslims destroyed no Hindu or Buddhist temples in the country.

${ }^{36}$ Ibid., pp. 7-8.

${ }^{37}$ They were Maulana Malik Ibrahim, Sunan Ampel, Sunan Bonang, Sunan Giri, Sunan Drajat, Sunan Kalijaga, Sunan Kudus, Sunan Muria, and Sunan Gunung Jati. See Solichin Salam, Sekitar Walisanga (Kudus: Menara Kusus, n.d.). 
As he puts it:

When [the Kingdom of] Majapahit fell, the Hindus, who remained faithful to their religion, fled to the island of Bali where the worship of Civa is still the prevailing religion. A clear picture may be drawn, i.e. that there was no [armed] struggle in the country between Islam and Hinduism. Both Islam and Hinduism belonged to the country, and civil war in the name of religion did not take place at all. ${ }^{38}$

The Hindu temple Prambanan in Yogyakarta and the Buddhist temple Borobudur in Magelang, for example, remained intact when Muslims spread Islam in that part of Java. Since Muslims did not destroy any Hindu or Buddhist temple when Islam spread in Indonesia, there was no conflict and all three religions could live peacefully together and cooperate in the country. Both Hindus and Buddhists did not wait for a chance to take revenge against Muslims as the latter also did not use violent means or took up arms when they spread Islam. The Muslims used no force to convert Hindus and Buddhists to Islam but they converted naturally. This harmonious relation has remained favourable until now.

On 16 March 1970, the World Council of Churches invited Mukti Ali to deliver a speech at the Consultation on Dialogue between Men of Living Faiths held in Ajaltoun, Beirut, Lebanon. In this international meeting, he delivered a paper entitled "Dialogue between Muslims and Christians in Indonesia and its Problems." "39 He shared information on the disharmonious relation that prevailed in Indonesia between Muslims and Christians in the 1970s. This relation was caused by, among other things, Christian propaganda in its attempt to convert Muslims to Christianity. As Mukti Ali described in his paper:

In Indonesia, the Muslims have been experiencing this kind of lies and slanders. The Christian preachers are consciously distorting the verses of the Qur'an for their propaganda purpose. The Adventist group, among the Christian denominations, could be considered as the most aggressive one, especially in its effort to visit the houses of Muslims when the husbands

${ }^{38}$ Mukti Ali, The Spread of Islam in Indonesia (Jogjakarta: Jajasan Nida, 1970), p. 15.

${ }^{39}$ Mukti Ali, "Dialogue between Muslims and Christians in Indonesia and its Problems," paper presented at the Consultation on Dialogue of Men of Living Faiths held by the World Council of Churches in Ajaltoun, Beirut, Lebanon, 16-25 March 1970. See his Dialog Antar Agama (Jogjakarta: Jajasan Nida, 1970), pp. 37-44. 
are not at home and try to entice their wives and children to Christianity. ${ }^{40}$

In response to this sensitive issue, the Indonesian government invited leaders of all religious groups to attend a meeting to solve the case. In the eyes of the government, this case should be resolved immediately so that interreligious tolerance and harmony could be maintained. Disharmonious relations between religious communities could disturb development programs whereas harmonious relations would contribute to the success of the implementation of these programs. Muslims, Protestants, Catholics, Hindus, and Buddhists leaders attended the meeting and discussed the case. During this important meeting, President Soeharto put forward a proposal that religious propagation by any religious group in the country should not be directed to followers of other religions. This proposal sounded wise and reasonable seen from the socio-cultural condition of Indonesia as a pluralistic society. The Muslims should not become the targets of Christian missionaries and likewise Christians (and other religious communities) should not become targets of Islamic propagation (dakwah). In the meeting, the leaders of Muslims, Hindus, and Buddhists accepted the government's proposal, but the leaders of the Protestants and Catholics rejected it, arguing that the proposal was contrary to the teachings of the Bible which urged its followers to spread their religion among people all over the world. ${ }^{41}$

On many other occasions, such as in his speech delivered to Christians during the Christmas celebrations on 25 December 1972 in Jakarta, Mukti Ali, as Minister of Religious Affairs responsible for interreligious dialogue, tolerance, and harmony across the country always reiterated the government's policy that religious propagation should not be directed at adherents of other religions. Referring to one of the important agreements adopted at the Council of World Churches held in Beirut 1972, he stated that no religion in the country was to try to attract people of other religions by using covered or uncovered methods, direct or indirect ways, or by exploiting poor, sick, and uneducated people. ${ }^{42}$ The agreement on the ethical principles of spreading religion adopted

\footnotetext{
${ }^{40}$ Ibid., p. 41.

${ }^{41}$ Ibid., p. 42.

${ }^{42}$ Mukti Ali, "Orang Yang Sudah Beragama Jangan Menjadi Sasaran Penyiaran Agama” in his Agama dan Pembangunan, p. 42.
} 
at the Council of World Religions is in fact in line with the contents of the regulation of the Minister of Religious Affairs of the Republic of Indonesia no. 70/1978. Adherents and preachers of all religions should employ these ethical principles in spreading religion because these principles are in accordance with the teachings of all religions and with human rights.

Muslims also strongly reacted against the building of churches by Christians in some parts of the country. The building of churches took place in predominantly Muslim areas where Muslims firmly objected and reacted. Tensions and conflicts between the two religious communities were inevitable. One of the churches the Christians built in 1970s was a big church in a Jakarta suburb to which Muslims strongly objected and reacted. Actually, there already were five churches available in the area, but the Christians erected a new big one in the centre of a predominantly Muslim area. This created disharmonious relations between Muslims and the Christians. Mukti Ali shared information about this case when he delivered his speech at the Consultation on Dialogue between Men of Living Faiths held from 16-25 March 1962 at the World Council of Churches in Ajaltoun, Beirut, Lebanon. By informing the other participants of this 'unfavourable' situation, he hoped that the same problem or similar incidents would not occur in other countries. He stated:

... sporadic explosion of conflict between the Christians and the Muslims in more than one place in Indonesia has occurred. These conflicts are caused mainly by the provocation of Christians. The building of churches in the predominantly Muslim surrounding naturally leads to unfavourable reaction from the part of the local inhabitants. As an illustration, an accident occurred in the suburb of Djakarta, the capital of Indonesia. The real cause of the accident was the building of a church in predominantly Muslim area. Out of the 36,000 inhabitants, 35,650 of them are Muslims. And for these 350 Christians, they built a new church at the centre of purely Muslim surrounding, besides other five churches available to them. The Muslims regarded this as an offence and provocation. Besides, projected against the poor and backward economic condition of the Indonesian people in general, this lavish spending and prodigal extravagance in erecting these huge and empty buildings could not be interpreted other than a displaying of wealth and material allurement, 
while the great number majority of the Indonesians do not have the chance to look forward further than to get a handful of rice for the next meal. When an accident really occurred afterwards, the Christians tried to incite public opinion to blame the Muslims for being aggressive and intolerant. This sort of accident has really a far-reaching consequence and has burned sentiment of the Muslims. ${ }^{43}$

Again, the government quickly responded to the explosive situation mentioned above. The Minister of Religious Affairs and Minister of Domestic Affairs issued joint regulation no. 01/Ber/Mdn-Mag/1969 stating that the construction of a house of religious worship should secure approval from the head of the region and from the local people living in the area where a house of worship would be erected. In addition to these conditions, the building of a house of worship by a certain religious community should be consulted with the head of the regional office of the Department of Religious Affairs and, if needed, with the leaders of socio-religious organisations. The establishment of a house of worship should also consider the city planning where a house of worship would be built. With the issuance of this regulation, religious tensions and conflicts, especially between Muslims and Christians, in Indonesia was expected to be minimised.

At the start of 2000 , to maintain interreligious tolerance and harmony, the Minister of Religious Affairs established the Center for Interreligious Harmony at the Ministry and the Regional Forum on Interreligious Harmony in many regions to function as venues for interreligious dialogue, consultation, and tolerance. The next development was the joint regulation of the Minister of Religious Affairs and the Minister of Domestic Affairs no. 01/Ber/Mdn-Mag/1969 which was replaced by the joint regulations of the Minister of Religious Affairs and Minister Domestic Affairs nos. 9/2006 and 8/2006. The replacement had to be made to accord with the implementation of regional autonomy where many policies, powers, and authorities had been transferred to the heads of regions in the country. According to the new regulation, groups of religious communities who wanted to erect of a house of worship should comply with the following regulations; 1 ) There should be at least 90 users of the house of worship. A list of their names and signatures

${ }^{43}$ Mukti Ali, “Dialogue between Muslims and Christians,” pp. 41-42. 
should be handed in. Their Kartu Tanda Penduduk/KTP (Indonesian Identity Card) should be attached to the paper. The paper bearing their names and signatures should be officially legalised and stamped by a local officer; 2) The establishment of a house of worship should be approved by at least 60 local people adhering to another religion. Their approval should be shown on a paper containing their names and signatures. The paper bearing their names and signatures should be officially legalised and stamped by the lurah (head of village); 3) The building of a house of worship should secure the written recommendation of the head of the Regional Office of the Department of Religious Affairs; 4) The erection of a house of worship should obtain a written recommendation from the head of the Regional Forum of Interreligious Harmony (FKUB, Forum Kerukunan Umat Beragama). ${ }^{44}$

The government of Indonesia has made every effort to eliminate religious tensions and conflicts among peoples of different cultures and religions by issuing and applying the above mentioned regulation. It has been reported that the People's Representative Council (DPR, Dewan Perwakilan Rakyat) is at present drafting a law on interreligious harmony to replace this regulation. When, in the near future, the DPR approves this draft, it becomes law, meaning that interreligious tolerance and harmony will have a stronger legal and constitutional status. Despite the government's efforts, tensions and conflicts still occurred in various parts of the country including, to mention some, the Ambon conflict between Muslims and Christians in 1999, the Poso clash between Muslims and Christian in 2000, ${ }^{45}$ and the Madurese-Dayak conflicts in Pontianak, Kualakapus, and Sampit (West Kalimantan) in 2000.

Initially, the Ambon incident -like the Poso conflict- was purely social but subsequently, religious sentiments entered the escalating conflict. Many Muslims and Christians were killed in the Ambon and Poso conflicts and houses belonging to the two communities were also

${ }^{44}$ See Peraturan Bersama Menteri Agama dan Menteri Dalam Negeri Nomor 9 Tabun 2006 dan Nomor 8 Tabun 2009 (Jakarta: Puslitbang Kehidupan Keagamaan Badan Litbang Agama dan Diklat Departemen Agama RI, 2006), p. 23

${ }^{45}$ For a detailed account of the Poso conflict, read S. Sinansari Ecip dan Darwis Waru (eds), Kerusuban Poso yang Sebenarnya (Jakarta: Global Mahardika, 2001). 
destroyed. ${ }^{46}$ The Ambon and Poso clashes ended when Muslim and Christian leaders signed a peace agreement in Malino (South Sulawesi) in 2002. ${ }^{47}$ The Pontianak, Kualakapuas, and Sampit cases were purely ethnic conflicts involving Madurese and Dayaks. Many Madurese were killed and expelled from these areas while the Dayaks burned and destroyed their houses and other properties. ${ }^{48}$ All these conflicts were finally resolved. At the beginning of 2012, the Muslims and Christians in Ambon again were involved in a conflict, but it was quickly resolved.

Tensions and conflicts between Muslims and Christians took the form of the burning of a church by Muslims at Meulaboh, Aceh, in the 1970s. Claiming their province as the Veranda of Mecca, the Acehnese Muslims did not want to see churches in the area. Almost at the same time, Muslims strongly opposed and succeeded in rejecting the planning of the international meeting of Council of World Churches to be held in Indonesia. In the eyes of Muslims, it was not appropriate to hold that kind of meeting in Indonesia where the majority of people are Muslim. Furthermore, in 2000 a group of radical Muslims bombed various churches on Christmas Eve in some cities in Java. Members of this group were also responsible for the Bali bombing in 2002 that killed more than two hundred people, most of them foreigners. Three masterminds, i.e. Amrozi, Imam Samudra, and Muchlas were sentenced to death and have been executed. They were closely linked with Dr. Azahari, a Malaysian terrorist who operated in Indonesia. ${ }^{49}$ A few months ago, another mastermind, known as Umar Patek, accused of being responsible for the bombing of churches on Christmas Eve in some cities in Java (2000) and

${ }^{46}$ In my capacity as Secretary General of the Ministry of Religious Affairs, I was included as a member of the Team for Conflict Resolution organised by the Coordinating Minister of Social Welfare (Jusuf Kalla). When the team visited Ambon and Poso, in both places I myself witnessed that many houses belonging to Muslims and Christians were burnt and destroyed.

${ }^{47}$ As a representative of the Ministry of Religious Affairs as well as in my capacity of official witness, I put my signature on the document of the peace accord.

${ }^{48}$ As Secretary General of the Ministry of Religious Affairs, I paid an official visit to Pontianak and I myself witnessed that Madurese houses and properties were burnt and destroyed by the Dayaks.

${ }^{49}$ Initially, the Indonesian police had difficulty in arresting Dr. Azahari. However, on 9 November 2005, Dr. Azahari was shot to death in Batu, Malang, and his body was sent to his family in Malaysia. 
the Bali bombing (2002) as already mentioned above was arrested. Now, he is on trial for terrorism. As far as Dulmatin -linked also to this terrorist group- is concerned, he was shot to death by the police in Tangerang.

To avoid tensions and conflicts among people of different cultures and religions, intercultural and interreligious dialogue and tolerance should always be promoted, strengthened, and put in action. Both as a scholar and as Minister of Religious Affairs, Mukti Ali played a pivotal role in promoting, strengthening, and implementing interreligious dialogue, tolerance, and harmony in the country. He proposed the principle of "agree in disagreement" to build and strengthen dialogue, tolerance, and harmony among people of different cultures, traditions, and religions. Prior to stressing his opinion, he outlined the following ideas, methods, and approaches proposed by various scholars to the building and strengthening of interreligious dialogue and tolerance:

First, a syncretistic approach that considers all religions as basically the same. In this approach, all religions are like waves that come in from one and the same ocean. All religions are just different ways to God, the Creator. Radhakrishnan, an Indian philosopher is one of the leading scholars who preach this idea. The advocates of syncretism are of the opinion that, by believing that all religions are the same, people of different religions can be harmonised and united in such a way as to avoid tensions and conflicts among them. Mukti Ali quoted a syncretist as saying: "I myself do not believe in religion except a religion which is believed by all men in all places." This kind of belief is also called "pantheism", meaning all things in the world are God and God exists in all hearts of men. Mukti Ali rejected this approach, arguing that in Islam, for example, it should be clear who the Creator (God) is and who man (creature) is. God as the Creator is totally different from man as a creature. ${ }^{50}$

Second, a re-conceptional approach that believes that men need a religion. According to this approach, it should be a common religion in which all men believe. By believing and subscribing to this common religion, there will be no tensions and conflicts among people of different cultures, traditions, and religions. Mukti Ali does not accept this idea or

${ }^{50}$ Mukti Ali, Kuliah Agama Islam di Sekolah Staf dan Komando Angkatan Udara Lembang (Jogjakarta: Jajasan Nida, 1970), pp. 18-21. 
this approach arguing that religion is not a product of thinking. Religion is God's revelation, not a human product. It is not reason that creates religion, but religion that guides man in employing his/her reason. ${ }^{51}$

Third, a synthetic approach, i.e. the creation of a new religion whose elements are taken from different religions. By doing so, people of different religions arrive at the agreement to believe and subscribe to this newly created religion because they feel that elements of the doctrine of their religion have been included and integrated into this new religion. Mukti Ali rejects this idea on the ground that this synthetic religion cannot be created. He argues that each religion has its own history, creed, doctrine, and tradition and, therefore, it is impossible to create a new religion by taking and including elements of each religion into the new religion. ${ }^{52}$

Fourth, a proselytising approach, i.e. replacing the religion of other people with one's own religion. By doing so, it is believed that interreligious tolerance and harmony can be established since many adherents of different religions convert and subscribe to one's own religion. Mukti Ali rejects this approach because it will in fact create tensions and conflicts among people of different cultures and religions. Converting people of different religions, let alone if bad or unfair methods are used, will provoke strong reactions and this will create explosive tensions and conflicts between religious communities. ${ }^{53}$

Fifth, an 'agree in disagreement' approach that lets each religious community be free to believe and practice its own religion. At the same time, adherents of a religion do not interfere with the internal affairs of other religions. Each religious community should respect and thus tolerate the other so that tolerance and harmony among people of different cultures and religions can be strengthened and maintained. Mukti Ali adopts this approach, arguing that this idea is applicable to Indonesia as a pluralistic society. ${ }^{54}$

By adopting this approach, it is obvious that Mukti Ali was an advocate and preacher of promoting, strengthening, and conducting dialogue, tolerance, harmony, and peace among people of different

${ }^{51}$ Ibid., pp. 21-23.

${ }^{52}$ Ibid., p. 23.

${ }^{53}$ Ibid., p. 24.

${ }^{54}$ Ibid. 
cultures and religions. Mukti Ali' ideas and views reflect the teaching of Islam in the Qur'an which says: "For you is your religion and for me is my religion," ${ }^{25}$ which is the theological basis of religious tolerance in Islam. There should be no interference in other religions; everyone and each community is free to choose a religion because religious freedom is one of the fundamental rights of man. This religious freedom is also stated in article 29 of the 1945 Indonesian Constitution.

I believe Mukti Ali's vision, views, and ideas on interreligious dialogue, tolerance, and harmony, either direct or indirect, inspired and influenced younger scholars and intellectuals in promoting and advocating the purpose. Scholars like Djohan Efendi, Nurcholish Madjid, Dawam Raharjo, Syu'bah Asa, Abdurrahman Wahid, Azyumardi Azra and others, some of whom in 1970s, attended the Limited Group discussions organised in Mukti Ali's home are intellectuals who continue Mukti Ali's ideas and efforts. That is to say Mukti Ali is dead physically, but he is still very much alive in terms of spirit, ideas, and efforts in promoting, strengthening, and preserving interreligious dialogue, tolerance, and harmony.

\section{E. Conclusion}

To conclude we may say that Mukti Ali, both as a scholar and as Minister of Religious Affairs showed his commitment and devotion to dialogue, tolerance, and harmony among people of different traditions, cultures, and religions. Both in his academic works and in his actions, he paid much attention to these issues. His role and contribution in the development of Indonesian intellectual and education is clear when one put his ideas and activities in the context of the history of the nation.

One may also relate Mukti Ali's educational background at the Institute of Islamic Studies at McGill University which enabled him to come to the fore to promote and strengthen dialogue among people of different faiths in the Indonesian pluralistic society, consisting of various ethnic groups, local languages, traditions, cultures, and religions. Living in such a pluralistic society, intercultural and interreligious dialogue and tolerance should be strengthened and maintained so that harmony, security, and peace can be felt and experienced by everyone. As described

${ }^{55}$ Sura al-Kāfirūn: 6. 
Following Mukti Ali’s Path

above, Mukti Ali outlined five approaches to achieve his goal. Particularly, Mukti Ali uphold the fifth one, i.e. 'agree in disagreement' which suits the Indonesian context until today. 
Faisal Ismail

\section{BIBLIOGRAPHY}

Ali, A. Mukti, Agama dan Pembangunan di Indonesia, Jakarta: Departemen Agama RI, 1972.

----, Alam Pikiran Islam Modern di India dan Pakistan, Bandung: Mizan, 1993.

----, Alam Pikiran Islam Modern di Indonesia, Jogjakarta: Jajasan Nida, 1969.

----, An Introduction to the Government of Aceh's Sultanate, Jogjakarta: Jajasan Nida, 1971.

----, Asal Usul Agama, Jogjakarta: Jajasan Nida, 1969.

----, Bagaimana Menghampiri Isra' Miradj Nabi Besar Mubammad S.A.W. (Islam dan Ilmu Pengetahuan), Jogjakarta: Jajasan Nida, 1969.

----, Beberapa Masalah Pendidikan di Indonesia, Jogjakarta: Jajasan Nida, 1971.

----, Beberapa Persoalan Agama Dewasa Ini, Jakarta: Rajawali, 1981.

----, Dialog Antar Agama, Jogjakarta: Jajasan Nida, 1970.

----, Etika Agama dalam Pembentukan Kepribadian Nasional dan Pemberantasan Kemaksiatan dari Segi Agama Islam, Jogjakarta: Jajasan Nida, 1969.

----, Ibn Chaldun dan Asal Usul Sosiologi, Jogjakarta: Jajasan Nida, 1970.

----, Ilmu Perbandingan Agama: Sebuah Pembahasan tentang Methodos dan Sistima, Jogjakarta: PT Al-Falah, 1964.

----, Islam dan Sekularisme di Turki, Jakarta: Djambatan, 1994.

----, Ke-Esaan Tuban dalam Al Qur'an, Jogjakarta: Jajasan Nida, 1969.

----, Kuliah Agama Islam di Sekolah Staf dan Komando Angkatan Udara Lembang, Jogjakarta: Jajasan Nida, 1970.

----, Masalah Komunikasi Kegiatan Ilmu Pengetabuan dalam Rangka Pembangunan Nasional (dengan Kelompok Agama), Jogjakarta: Jajasan Nida, 1971.

----, Memahami Beberapa Aspek Ajaran Islam, Bandung: Mizan, 1991.

----, Metode Memahami Agama Islam, Jakarta: Bulan Bintang, 1991.

----, Modern Islamic Thought in Indonesia, Jogjakarta: Jajasan Nida, 1969.

----, Pelbagai Persoalan Islam di Indonesia Dewasa Ini, Jogjakarta: Jajasan Nida, 1970. 
----, Pemberontakan Abmad Urabi atau Perjuangan Konstitusi di Mesir dan Gerakan Imam Mabdi di Sudan, Jogjakarta: Jajasan Nida, 1971.

----, Religion and Development in Indonesia, Jogjakarta: Jajasan Nida, 1971.

----, The Spread of Islam in Indonesia, Jogjakarta: Jajasan Nida, 1970.

Azra, Azyumardi and Saiful Umam et al. (eds), Menteri-Menteri Agama Republik Indonesia: Biografi Sosial Politik, Jakarta: Badan Litbang Agama Departemen Agama in collaboration with the PPIM-IAIN Syarif Hidayatullah, 1989.

Basuki, A. Singgih, "Kontekstualisasi Agama dalam Pemikiran Mukti Ali," Dissertation submitted to Pasca Sarjana UIN Sunan Kalijaga, Yogyakarta, 2012.

Boland, B.J., The Struggle of Islam in Modern Indonesia, The Hague: Martinus Nijhoff, 1971.

Damami, Mohammad et al., "Prof. Dr. H.A. Mukti Ali" in Lima Tokoh LAIN Sunan Kalijaga, Yogyakarta: IAIN Sunan Kalijaga, 2000.

Departemen Agama RI, Kompilasi Peraturan Perundang-undangan Kerukunan Hidup Umat Beragama, Jakarta: Proyek Peningkatan Kerukunan Hidup Umat Beragama dan Pengembangan Agama Departemen Agama RI, 1998.

Djam'annuri (ed.), 70 Tabun H.A. Mukti Ali: Agama dan Masyarakat, Yogyakarta: IAIN Sunan Kalijaga Press, 2001.

Ecip, S. Sinansari and Darwis Waru (eds), Kerusuban Poso yang Sebenarnya, Jakarta: Global Mahardika, 2001.

Efendi, Djohan and Ismet Natsir (eds), Pergolakan Pemikiran Islam: Catatan Harian Ahmad Wahib, Jakarta: LP3ES, 1981.

Geertz, Hildred, "Indonesian Cultures and Communities," in Ruth T. McVey (ed.), Indonesia, New Haven: Yale University Press, 1963.

Ismail, Faisal, Pijar-Pijar Islam: Pergumulan Kultur dan Struktur, Yogyakarta: LESFI, 2002.

Madjid, Nurcholish, "Islamic Roots of Modern Pluralism: Indonesian Experiences," Studia Islamika, vol. 1, no. 1 (April-June 1994), pp. 55-77.

Munhanif, Ali, "Prof. Dr. A. Mukti Ali: Modernisasi Politik-Keagamaan 
Orde Baru" in Azyumardi Azra and Saiful Umam et al. (eds), MenteriMenteri Agama Republik Indonesia: Biografi Sosial Politik, Jakarta: Badan Litbang Agama Departemen Agama bekerja sama dengan PPIMIAIN Syarif Hidayatullah, 1989.

Mustoha at al. (eds), Bingkai Teologi Kerukunan Hidup Umat Beragama di Indonesia, Jakarta: Badan Litbang Agama Departemen Agama RI, 1997.

Peraturan Bersama Menteri Agama dan Menteri Dalam Negeri No. 01/ Ber/Mdn-Mag/1969.

Peraturan Bersama Menteri Agama dan Menteri Dalam Negeri Nomor 9 tahun 2006 dan Nomor 8 tahun 2009, Jakarta: Puslitbang Kehidupan Keagamaan Badan Litbang Agama dan Diklat Departemen Agama RI, 2006.

Peraturan Perundang-undangan Kehidupan Beragama, Jakarta: Proyek Pembinaan Lembaga Keagamaan Departemen Agama RI, 1999.

Ropi, Ismatu, Fragile Relation: Muslims and Christians in Modern Indonesia, Jakarta: Logos Wacana Ilmu, 2000.

Salam, Solichin, Sekitar Walisanga, Kudus: Menara Kudus, n.d.

Watt, W. Montgomery, Muslim-Christian Encounter: Perceptions and Misconceptions, London: Routledge, 1991.

Zeberi, Kate, Muslims and Christians: Face to Face, Oxford: One-world Publications, 1997. 